\title{
Pedagogika jako věda a jako společenský úkol - inspirace z myšlenkové dílny Johna Deweyho
}

\section{Markéta Čermáková}

\begin{abstract}
Abstrakt
Cílem příspěvku je připomenout několik myšlenek Johna Deweyho, jež mají souvislost se soudobými úvahami o obecné pedagogice. Jde zejména o otázku vlivu podstatných společenských změn na výchovnou praxi a na budování pedagogické teorie. Zrychlující se dynamika rozvoje v ekonomické i technické oblasti vyvolává nové společenské potřeby. V edukační teorii hraje stále větší roli vliv sociální prostředí, ve kterém člověk vyrůstá. Text konstatuje, že Dewey jako první systematicky pokládal společenské prostředí za specifické východisko i hybnou sílu mentálního a emocionálního rozvoje dítěte, za živnou půdu pro jeho další rozvoj a vzdělávací možnosti. Deweyovské propojení teorie výchovy s analýzou sociálního prostředí implikuje odmítnutí pokusů o nezávislost pedagogiky na jiných vědních disciplínách a na filosofii. Text rovněž připomíná Deweyho názor, že výchovné a vzdělávací aspekty nejsou vlastní pouze situacím ve škole, ale $i$ běžnému životu. $V$ (post)moderní době se však ono edukační prostředí neustále proměňuje, a tak je dodnes živá a otevřená Deweyho otázka: Ize (př́p. jak) formulovat nosné a perspektivní výchovné cíle pro neustále se měnící a diverzifikovanou společnost?
\end{abstract}

Klíčová slova: výchova, tradice, zkušenost, praktičnost, životní podmínky, společenské změny, škola 


\begin{abstract}
The aim of this paper is to recall a few ideas of John Dewey, related to the contemporary considerations of general education. It is mainly the question of the impact of significant social changes on educational practice and on creation of educational theory. The accelerating pace of development in both the economic and technical areas gives rise to new social needs. The impact of social environment one grows up in plays an increasingly larger role in educational theory. The paper notes that Dewey was the first to consider social environment to be the basis and driving force of the mental and emotional development of a child, a breeding ground for its future development and educational opportunities. Dewey's theory linking education with the analysis of social environment implies rejection of attempts at independence of pedagogy from other disciplines and philosophy. The text also recalls Dewey's view that the educational aspects are specific not only about the situations at school but also about everyday life. In the (post) modern times, however, the educational environment is constantly changing, and thus Dewey's question is still up to date: is it possible to define sound and promising educational objectives for constantly changing and diversified society?
\end{abstract}

Keywords: education, tradition, experience, practicality, living conditions, social changes, school.

\title{
Úvod
}

Věda není nikdy tak neutrální, jak o sobě často a ráda prohlašuje, protože přinejmenším proměňuje svět, ve kterém žijeme. Postmoderní doba přinesla řadu zásadních otázek týkajících se mimo jiné toho, čemu říkáme "základy vědy“ " „vědní profil“ nebo „vědní identita". S otázkami tohoto druhu se setkáváme i v pedagogice. V důsledku zpochybnění tradičních odpovědí na otázky, jimiž se pedagogové zabývali a zabývají, se objevují návrhy alternativních výchovných modelů a dokonce snahy nahradit pedagogické myšlení a problémy právní terminologií v rámci ochrany práv dítěte apod. Současně se z horizontu pedagogické vědy ztrácí zaměření na celek a na cíle, které bývaly přirozenou součástí moderního chápání pedagogiky. Ty se však možná pod vlivem určitých společenských pohybů a ve světle soudobého pojímání smyslu a funkce pedagogiky dostaly do pozadí.

$\checkmark$ tomto krátkém zamyšlení si chci položit otázku po povaze a úkolu pedagogické vědy v dynamicky se rozvíjející společnosti. Vymezit pedagogiku jako určitý druh vědy a zároveň jako společenský úkol je pokus, který může v kontextu postmoderních zpochybnění role společenské angažovanosti a pokusů o ideologickou dekonstrukci vypadat podezřele. Moje zamyšlení chci proto opř́it o myšlenky myslitele, u něhož bylo 
zmíněné spojení teorie se společenskou praxí nejen nedůkladněji propracováno, ale též zbaveno všech ideologických konotací, nebot' směřovalo k demokratickému ideálu jako nejvyšší vychovatelské hodnotě. Dovolte mi ale předeslat několik obecnějších poznámek na úvod, kdy nejprve shrnu obecná východiska své úvahy.

Západní společnost je od období raného novověku založena ideály dynamismu a změny. Tyto ideály se záhy staly součástí společenské praxe, která se začala čím dál více vzdalovat antickým a středověkým hodnotám kontemplativního života. Postupně se stalo zjevným, že v základu "věcí" jsou procesy a změny, jejichž tempo je často rychlejší, než by si lidé práli. I když se naopak jindy zdá, že společnost stagnuje, vývoj (byt' třeba nepozorovaně)nepřetržitě probíhá. Stále vzniká něco nového, nové kombinace vztahů, zvyklostí a objevů se začleňují do stávající sociální struktury, podílejí se na podobě budoucích změn v myšlení a jednání lidí, a rovněž zpětně ovlivňují každodennost tím, že proměňují její přirozené vazby a mezilidské vztahy.

Společnost provázejí změny samožrejmě po celou dobu její existence, nezačínají až v evropském novověku, společenské struktury nebyly nikdy zcela statické a ztuhlé. Ale jak ukázala Hannah Arendtová (Arendt 2009), teprve novověký člověk učinil ze změny samu podstatu svého života a neváhal opř́t o ni i své ideály a vize. Moderní obraz člověka je jiný, než v dobách klasických, před-moderních, není už statický, nemůže se již opírat o vztah ke zcela neměnným hodnotám. Potřebou moderního člověka bylo a je vytvořit obraz sebe sama a ideál lidství stejně dynamické, jako moderní společnost. Moderní věda o člověku proto podněcuje takový typ poznání, který by odpovídal a vyhovoval měnící se povaze společenské struktury.

Od raně moderních časů jsme se $v$ antropologických otázkách posunuli od teorie „myslící substance“ (subjektu) k teoriím pojednávajícím o člověku jako o proměnlivé a především jednající struktuře. Myšlenka historismu navíc definitivně podlomila víru ve stabilní podstatu či neměnné jádro lidské existence. Se změnou obrazu člověka se změnilo i prostředí, v němž člověk reálně žije a vyrůstá - i jeho výchova. Změnila se též podoba vědy, která vývoj a výchovu člověka studuje. Teorie výchovy v průběhu dvacátého století stále více zdůrazňovala význam vzdělávání, protože věda o výchově nahlédla, že pouze solidní, praktické a použitelné vzdělání dává člověku možnost adaptovat se na výzvy dynamicky proměnlivého světa a vytváŕí současně dispozice $k$ úspěšné činnosti. Moderní a postmoderní teorie výchovy, vzdělávání a učení již neslouží k prohloubení kontemplace nebo jen teoretického vědění, nýbrž jsou považovány za efektivní nástroj schopný přispět k rychlé adaptaci na sociální transformace, ale též za faktor sociálního vývoje, který se významně podílí na generování změn nových.

Připomínáme-li tedy kořeny moderní pedagogiky, je nutné přemýšlet o nich především v kontextu pojmů změny, inovace a pokroku. Současnost ale nelze chápat jako prosté pokračování, vyústění minulosti. Sociolog Gerhard Schulze $(1997$, s. 49) zdůrazňuje, že jeden z nejproblematičtějších rysů soudobé společnosti v minulosti vlastně vůbec neexistoval. V minulosti byly lidem známy cíle individuálního i společenského života, 
ovšem neměli vždy dostatečné prostředky k jejich dosažení. Dnes je tomu naopak míváme největší nejasnosti právě v otázce cílů. Schulze dále konstatuje, že v minulosti byly změny přetvářející společnost konstantní. At’ se měnilo cokoli, charakter změny zůstával stejný. $V$ dnešním světě se ale mění i povaha změn. V oblasti tzv. sociálního pokroku je tento jev pocit’ován nejsilněji - jsme znejistěni neschopností dospět ke „konci cesty", k všeobecně přijatelným řešením sociálních problémů, nebot každý krok na cestě pokroku otevírá nové perspektivy, generuje nové otázky, uvádí do chodu jinou kvalitu společenských pohybů.

Bezmála sto let je vidět snahy sociologů, pedagogů-teoretiků i praktických vychovatelů o přizpůsobení edukačních institucí rychlému tempu doby a novým společenským potřebám, vyvázat pedagogiku z čistě teoretických souvislostí a akademických měřítek a učinit ji skutečně praktickým nástrojem k dosahování individuálního úspěchu, životní spokojenosti a tím i společenského pokroku. Dodnes je otázka vztahu tradice a pokroku v edukaci jednou z nejdiskutovanějších. Domnívám se, že chceme-li pojmout pedagogiku nejen jako obecnou teorii výchovy člověka, ale i jako obor usilující o určité společenské dobro (které zde spočívá v pomoci člověku vyrovnávat se s rychle se měnícími požadavky doby), můžeme se inspirovat koncepcí Johna Deweyho, která se objevila ve zlomovém období rozvoje v oblasti ideové, vědecké i technické a jejíž vliv zaznamenáváme v mnoha didaktických a obecně pedagogických idejích i v praxi. Pokusím se vyložit, proč právě odkaz tohoto myslitele považuji za trvale inspirující pro řešení některých obecných problémů pedagogiky jako vědy situované do provozu soudobé společnosti. V Deweyho teoretickém rozvrhu pedagogiky lze nejen vystopovat dobře promyšlený rozchod s tradicí tzv. herbartovské pedagogiky, ale - a to je to, co považuji za vysoce oslovující - právě v jeho učení jakoby kulminovalo promýšlení rychlých společenských změn ve vztahu k otázce smysluplné výchovy pro budoucnost. Tím nám je jeho uvažování stále blízké, v některých momentech se ukazuje dokonce jako nadčasové. Ponechávám stranou zásadní inspirační vliv, který měl na pedagogiku dvacátého století v oblasti obecné didaktické teorie a v tzv. experimentálním alternativním hnutí.

\section{Pedagogika změny a rekonstrukce}

Dewey pevně svázal otázku pedagogiky s ideou důležitosti vzdělání chápaného jako předpoklad možnosti adaptace na stále se vyvíjející společenské potřeby. Odmítl všechny předem určené či dlouhodobě plánované koncepty výchovy a po Jamesově př́kladu zdůrazňoval ve všech praktických disciplínách, zejm. etice a pedagogice, ${ }^{1}$ význam pohybu, změny, pokroku a především stálou proměnlivost výchovných cílů. Klademe-li si dnes otázku po povaze či identitě obecné pedagogiky, je podle mého soudu inspirativní obrátit se k dílu tohoto amerického polyhistora proto, že pedagogickou vědu nechápe

1 Dewey chápe jako praktický obor též teorii poznání. 
jen jako teoretické poznávání výchovné skutečnosti, ale také a zejména jako úkol, kterým je člověk zkoumající otázky edukace pověěen samotnou společností. Pedagogika se tak v Deweyho pojetí stává nejen systematickým úsilím o poznání podstaty výchovy, ale i analýzou společenských potřeb, jimž musí pedagog jít vstříc a koncipovat své vědění tak, aby napomohl přicházející generaci ke společenské adaptaci.

Typ, resp. kvalitu výchovy Ize hodnotit podle toho, do jaké míry vzbuzuje v dítěti touhu po neustálém osobnostním růstu a do jaké míry umožňuje vytvářet prostředí, které by, slovy Deweyovými, přecházelo v účinné konání (Dewey 1932, s. 77). Výchova plně spočívá na myšlence rozvoje a permanentní rekonstrukce zkušenosti, v níž nemá smysl definovat nějaký poslední a dokonalý cíl. Mnohem spíše jde o hledání podmínek k překonávání aktuálního poznání, dovedností, postojů apod. ve světle nově příchozích impulzů z užšího i širšího prostředí.

Spolu s Deweyem můžeme proto žádat, aby škola nevzdalovala dítě od života, ale aby naopak život vnikl do školních tříd. Jistě že ne se vším všudy, jak by se mohl někdo domnívat na základě poněkud ožehavých formulací (asi bychom nežádali, aby do škol pronikl život takový, jaký je „na ulici“). Dewey rozumí životu především jako neutuchající činnosti, jež nás chybami učí, jak jednat správně. Z této ideje plyne, že učit se (alespoň zpočátku) mohou děti jen zcela konkrétně na věcech a činnostech běžného života. Dewey obhajuje zásady, že škola by neměla učit slovům, nýbrž věcem, které jsou podpořeny činným tvořením, ne pouze přejímáním. Žádná osobní zkušenost se nedá přenést do nitra jiného člověka, proto je třeba vše vyzkoušet a zkušenost budovat zevnitř. ${ }^{2}$

Je charakteristické, že v experimentálních školách se podle Deweyho mají pěstovat ty nejryzejší, s životem provázané činnosti; tj. ty, které dříve tvořily základ lidských zaměstnání v domácnostech, ale díky modernímu průmyslu se staly "neviditelnými“ a pro dítě běžně nedostupnými. Jenom důrazem na praktické činnosti a přiblí̌ením k životu může škola dítě přesvědčit o nutnosti a užitku rádu a organizace, o významu společenství a kooperace, zformovat jeho zpočátku jen intuitivní a nevytříbený zájem a učinit pro dítě a dospívajícího školu atraktivní. Heslo, které vzešlo z jeho myšlenkové dílny, „Ispojit školu se životem" předpokládalo, že pro dítě se škola stane atraktivní skrze jeho vlastní zkušenost a činnou praxi. Dewey přitom škole nepřipisoval žádný zázračný účinek ani nedosažitelný cíl. Škola nikdy nenadělí a nevytvoři žádnou definitivu ani v mravním, ani profesním ohledu. Může ale dodat dítěti prostředky k rozvoji celoživotní sebevýchovy.

Nejdůležitějším základem pedagogiky je proto podle Deweyho psychologické prozkoumání a podchycení zájmu, nebot u dítěte je zájem jakousi hnací silou, které má vychovatel dávat směr. To platí nejen pro vyučování určitým oborům, předmětům, ale též pro otázku mravního dobra. Východiska pro řešení mravně relevantních situací jsou stejná, jako východiska k řešení teoretických problémů a k bádání v př́rodních vědách. Jsou ale v zásadě totožná i s východisky pro politický život, pro přebývání ve společenství. I v morálce rozhoduje hlavně experiment a zkušenost, Dewey se proto domníval, že

2 Žák, který se chce něco naučit, neposlouchá jako pes, ale snaží se jednat jako pán (Dewey 1904, s. 77). 
i v této oblasti jsou možné nové objevy a vynálezy. Nehledal „věčné hodnoty“, nechtěl o mravnosti jen diskutovat a kodifikovat statický systém mravních pravidel, nebot’ tím nelze v mravním stavu světa nic vylepšit. Diskutovat o všeobecných zásadách etiky je zbytečné, nebot' mravní svět je tvořen konkrétními situacemi, ${ }^{3}$ jež vyžadují činnost, rozhodnost, podnikavost a samostatnost. Navíc situacemi, jejichž okolnosti se neustále mění, v duchu poněkud rozšířené Jamesovy teze o duševním životě: nejen vědomí, ale veškerá skutečnost se děje jako neustálý tok či proud (srv. Strouhal 2013, s. 69). Společenský vývoj přináší nová mravní "a priori“, jejichž původ neleží v jakési hluboké a věčné mravní struktuře subjektu, nýbrž v principech lidského společenství v určité fázi vývoje (Dewey 1929).

Dynamický způsob Deweyova myšlení nikdy nepodporoval myšlenku hledání „trvalých" (nadčasových) cílů, nýbrž naopak, usiloval o pedagogiku flexibilní, pozornou k vývojovým změnám a konkrétním okolnostem výchovy a neutuchající rekonstrukce dětské zkušenosti. Žák ve škole musí pocítit nerovnováhu svých znalostí a myšlenek s předkládanými tematickými celky. Učitel by neměl zapomínat na to, že žák není neaktivním př́ijemcem cizích zkušeností, ale aktivní hráč v procesu učení, protože si s sebou přináší zpưsoby chování a očekávání z minulých událostí (Hickman 2009, s. 9). Dewey nás poučuje, že pedagogika nemá být jen teorií velkých cílů, ale také a především hledáním podmínek k spontánní tvorbě menších, o to však účinnějších kroků na cestě dítěte k dospělosti. Na cestě, jejíž průběh není předem znám, nýbrž je v každém okamžiku teprve v procesu tvorby.

\section{Filosofie jako relativizace a jako obecná teorie výchovy}

Výchova člověka spočívá podle Deweyho v neustálém obnovování významu aktuální zkušenosti (tj. v její rekonstrukci), jež se děje víceméně nahodilým přenášením zkušeností při každodenním styku lidí. Pedagogika však usiluje o zkušenostní rekonstrukci úmyslnou, záměrnou, aby se udržela kontinuita určitých hodnot a postojů, určitých forem vědění a způsobů myšlení. To je základem dějinnosti lidského společenství a kulturních tradic.

Navzdory zřejmým konzervativním tendencím však mají společenské instituce a zvyklosti pouze relativní stálost a vždy je možné nahlížet na ně kritickou evoluční optikou. Chceme-li zjištovat fakta ve smyslu pravidelností a opakujících se zákonitostí, uspějeme patrně (a ještě ne zcela) ve vědách o prírodě. Chceme-li ale porozumět dějinám, společenskému životu a tomu, co nazýváme osobností, neobejdeme se bez filosofie. Pedagogika jako věda o výchově člověka má významný filosofický akcent. Př́rodní vědy jsou schopny odpovědět na otázku, které obecné pravdy platí o světě

${ }^{3}$ K tomuto problému lze odkázat již ve sporu aristotelské etiky s platónským pojetím dobra (Aristotelés 2009, 1096a15 a násl.). 
a co v určitém prípadě znamenají. Ucelenost poznání a možnost jeho praktické aplikace ale není důsledkem kvantitativního souhrnu dílčích „pravd“, je spíše produktem naší důslednosti, resp. pozorné snahy o sjednocení množství poznatků v účinnou a produktivní teorii schopnou měnit a vylepšovat podmínky našeho života. Filosofií se zde rozumí metoda, která umožní myslet skutečnost v proměnlivých souvislostech. Podle Deweyho obecné filosofické stanovisko záleží v tom, že nechce nic uznat za samostatné, izolované, protože se snaží zachytit každý děj v jeho souvislosti (Dewey 1904, s. 63). Filosofické myšlení je spojeno s pohledem do budoucnosti, v níž věci nejsou a nikdy nebudou dokončené a hotové. Každá společenská tř́da má jinou životní filosofii, jiné nazírání na svět. Různé skupiny provázejí rozdílné způsoby života s různými zkušenostmi, proto i rozvržení hodnot je rozdílné. Krátce, filosofie přináší do myšlení relativizující (tj. vztažný) moment jako nutný důsledek akceptace procesuality lidského světa a poznání.

Chceme-li na výchovu nazírat jako na tvorbu základních citových a rozumových stavů mysli se zřetelem k prírodě a bližním, je podle Deweyho dokonce možné definovat filosofii jako obecnou teorii výchovy. Nemá-li filosofie zůstat jen dogmatem, ř́ká Dewey, musí se její soud o minulé zkušenosti projevit v chování. Pokud nějaká filosofická teorie nevyvolá žádné změny ve výchovných snahách, musí být považována za umělou, abstraktní (Dewey 1932, s. 435). Pedagogika jako věda o uvádění člověka do vzájemně provázaných a úplných souvislostí života by měla "filosoficky" dbát na zajištění rovnováhy v rozmanitých činnostech, aby každá z nich propůjčovala ostatním význam a zase sama od nich význam dostávala. Takto produktivní výchova dává možnost proniknout k uchopitelnému významu mnohdy abstraktních filosofických spekulací. Teorie výchovy a filosofie jsou v těsném sepětí.

Dnes mj. i díky Deweyovi víme, že školní práce snadno sklouzává k empirické rutině, pokud nejsou její cíle a metody oživovány. Filosofie má v tomto prípadě dvojí úkol: posuzovat edukační cíle se zřetelem k dosavadnímu stavu vědeckého bádání, ale též ukazovat význam některých hodnot, aniž by zároveň nutně musela detailně promýšlet prostředky k jejich dosažení. Filosofie totiž reflektuje o ideálech. Musí ale též uvažovat o souvislostech výsledků vědeckého poznání a budoucího vývoje společnosti. Filosofie pomáhá pedagogům hledat metodu, jak využít lidskou poznávací sílu ve shodě s vážnými a promyšlenými názory na život a jeho smysl, ve shodě s ideály. Výchova je jakoby dílnou, v níž se filosofické ideje uskutečňují a zkouší. Domněnky, které se vyzkouší a ověři v praxi, pak mohou odpovědět na př́padné nejasnosti. Praktická filosofie je tedy teorií výchovy jakožto činnosti, jež promyšleně vykonává filosofii v praxi (Dewey 1932, s. 436).

Vždy, když západní civilizace procházela zlomovými momenty, objevil se myslitel, který se pokusil stanovit nový koncept výchovy odpovídající na nové potřeby proměněné civilizace. Tak se v období rozkladu Athén objevuje nová vychovatelská iniciace sókratovko-platónská, v době rozkladu scholastiky vystupuje Jan Amos Komenský, v období přechodu od agrární k průmyslové společnosti přijde na scénu John Dewey. I když se profiluje jako filosof a mluví především o pedagogice a psychologii, celá jeho 
koncepce byla nesporně vyvolána a uvedena $v$ život obrovskou sociologickou imaginací, tedy schopností vidět „pod povrch“ současnosti a vytušit hluboké změny, které proměny společnosti v budoucnosti přinesou. $A$ jak Dewey sám zdůraznil, změněná společnost si nutně vyžaduje změněnou výchovu: proměnu celého jejího jádra a určení.

\section{Od společenské adaptace $\mathrm{k}$ demokracii}

Dosud jsme připomínali hlavně Deweyho důraz na procesuální a proměnlivé okolnosti výchovy a na nutnost, aby pedagogika coby teorie takové výchovy člověka dokázala formulovat své prístupy, výklady a návody adekvátně skutečné povaze formativního procesu i reálné společenské situaci. Důležité je ale také upozornit na to, že společenskou adaptací se u Deweyho, podobně jako u Durkheima (srv. Strouhal 2010, např. s. 121-125), nemyslí jen socializační a v podstatě konformizující, normalizační procesy, nýbrž moralizujicí působení, jehož cílem je zformovat demokraticky smýšlející a vnitřně svobodné lidi ve svobodném státě. Pedagogika by proto měla přihlížet i k mravním a politickým kvalitám společnosti, k níz si má dítě utvořit pouto. Cesta ke svobodě a demokracii nemůže být dlážděna jen sérií individuálních adaptací konformních jednotlivců, prípadně úctou k autoritám a institucím.

Dewey předpokládal, že hlavním výchovným cílem je učinit z dítěte svébytného a odpovědného jedince, který bude schopen i v dospělosti ve své výchově pokračovat dále sám. To je vyjádřeno v principu demokratické výchovy. Principu demokracie tu nelze rozumět v úzce politickém smyslu, nýbrž tak, že demokratičnost v sobě zahrnuje jak odpor vůči dogmatismu, tak určitou energii k činnosti a k sebevýchově. Cíl demokratické výchovy proto nemůže být postulován mimo - vně výchovný postup. Dewey ukazuje, v čem spočivá rozdíl mezi cíli imanentními procesu výchovy, a cíli, jež jsou vytyčeny mimo tento proces, jakoby „nad ním“. Prvně jmenované člověka vnitřně motivují a udržují proces výchovy „v chodu“bez donucování. Jsou-li však dítěti cíle určeny zvnějšku (příkazem) a nevyplývají z vlastního volného rozvoje dětských zkušeností, jedná se spíše o prostředky k dosažení cílů zcela jiných lidí, než těch, kdo jsou vychováváni.

Výchova je nepochybně společenská činnost, jejímž měřítkem je určitý společenský ideál. Společnost se snaží vyvolat u všech svých členů podřizenost vůči společenským zvyklostem a normám. Společnost demokratická ale nahlíží, že jedinec není jen nástrojem sloužícím k udržení společnosti ve stavu, v jakém právě je; je zároveň i svébytnou osobností, jež se obrací ke své historii, kultuře i k prírodě, aby zde hledal inspiraci pro své působení ve světě, pro zdokonalení a zpresesnění chápání významu věcí, jež nás obklopují (Dewey 1932, s. 168). Výchova a vzdělávání mají lidský význam jen tehdy, provokují-li schopnost člověka stále rozšiřovat horizont rozumění a spektrum možností k jednání. 


\section{Závěr}

Rozhodně nechci tvrdit, že problémy, s nimiž se dnes při výchově a vzdělávání setkáváme, Ize vyřešit pouhým ohlížením se do minulosti a „opisováním" od velkých osobností. Už proto ne, že bych tím popřela východisko, jež jsem si k tomuto zamyšlení stanovila. Je-li v základu našeho života změna, musí být i pedagogika pozorná především k tomu, co je jakožto přicházející z budoucnosti skryto pod povrchem současných událostí. Znalost minulosti může inspirovat k hledání a nalézání významu určitých problémů současnosti, které pro zaujetí „aktualitou“ nejsme schopni vidět, nebo je jednoduše přehližíme. Minulost v sobě nemá charakteristické rysy přítomnosti a tak - i když je samozřejmě vždy určitým způsobem, tj. aktuálně „čtena“, vykládána - dává prítomnosti nový rozměr. Dewey se domníval, že důkladná znalost minulosti přináší triviální, avšak důležité zjištění: není třeba hledat řešení problémů, jejichž řešení již byla v minulosti nalezena. Snad bychom toto tvrzení mohli přeformulovat tak, že je důležité s minulostí neztratit spojení, abychom pochopili vývoj, jímž vývoj řešení určitých problémů prochází. Vědomá a reflektovaná vazba na minulost (dějinné vědomí) pak může pomoci i v tvorbě nových idejí a řešení dříve nevídaných (Dewey 1932, s. 103).

Nejen v pedagogice se dnes hovoří o nutnosti být připraven na společenské změny, naučit se je přijímat a přetavit do vlastního života. Rychlost změn se stále zvyšuje. Bez ohledu na možnost aktivně tyto změny ovlivňovat nebo je jen pasivně prijímat je pro fungování společnosti nutné, aby se schopnost adaptace na stále narůstající změny zvyšovala. Jen tak se tyto změny mohou stát pro člověka výzvami. Společenským změnám jakožto výzvám pak můžeme čelit jen nikdy nekončíím učením - vzděláváním. Společnost je komplexní systém, v němž je nutný alespoň minimální druh konformity a souhlasu s danými normami, hodnotami. Socializací je nám od narození vytvářen pocit nutnosti usilovat o cíle předepsané kulturním systémem, v jehož rámci se pohybujeme a jehož hodnoty integrujeme (Keller 1997, s. 91). Socializace uvádí jedince do společnosti a tlačí jej, aby se přizpůsobil. To vše je na první pohled ve shodě s deweyovskou teorií výchovy jako společenské adaptace.

Ve společnosti, jež má dosáhnout vedle technického i kulturního pokroku, však pouhá integrace nestačí. Pedagogové by měli rozumět svému společenskému úkolu. Vedle přizpůsobení a zákonů nabídky a poptávky je tu ještě jejich odpovědnost za určité hodnoty, které se nedají uchovat tržním způsobem života a pouhou adaptací na společenské potřeby. Úkolem pedagogiky na obecné, resp. nejzákladnější úrovni je proto promýšlet rozdíl mezi tím, co je skutečnou a co pouze zdánlivou společenskou potřebou (Strouhal 2010, s. 112). A zde se budeme vždy střetávat s deweyovským postřehem, jenž má daleko větší význam, než zdůraznění společenské adaptace: nemá-li pedagogika spočívat jen v teoretizování a nemá-li být hodnotově slepou, bude se muset angažovat i ve vnitřní obrodě společnosti, která bez patřičné výchovy degeneruje, zvláště pokud rezignuje na hledání nových nosných ideálů. Pedagogika je teorií rozvoje, teorií tvor- 
by nového. Deweyho odkaz je v tomto směru i v dnešní době živý a v tom nejlepším smyslu slova aktuální.

\section{Literatura}

ARENDT, H. (2009). Vita activa. Praha: OIKOYMENH.

ARISTOTELÉS (2009). Etika Níkomachova. Praha: Rezek.

DEWEY, J. (1932). Demokracie a výchova. Praha: Jan Laichter.

DEWEY, J. (1929). Rekonstrukce ve filosofii. Praha: Sfinx.

DEWEY, J. (1904). Škola a společnost. Praha: Jan Laichter.

HICKMAN, L. ed. (2009). John Dewey Between Pragmatism and Constructivism. New York: Fordham University Press.

KELLER, J. (1997). Úvod do sociologie. Praha: SLON.

SCHULZE, G. (1997). Constructing the New Consumer Society. New York: Palgrave Macmillan.

STROUHAL, M. (2010). Émile Durkheim - sociolog a pedagog. Praha: FF UK.

STROUHAL, M. (2013). Teorie výchovy. K vybraným problémům a perspektivám jedné pedagogické disciplíny. Praha: Grada.

\section{Kontakt:}

Mgr. Markéta Čermáková

Katedra pedagogiky FF UK

m.cermakovka@seznam.cz 